Abstracta Iranica Abstracta Iranica

Revue bibliographique pour le domaine irano-aryen

Volume 29 | 2008

Comptes rendus des publications de 2006

\title{
Osțūre-ye Tehrān. Tehrān, Daftar-e pažūheš-hā-ye farhangī, 1385, 250 p. (Majmū'e-ye Tehrānšahr, 1) [Le mythe de Téhéran]
}

\section{Bernard Hourcade}

\section{(2) OpenEdition}

Journals

Édition électronique

URL : http://journals.openedition.org/abstractairanica/29142

DOI : 10.4000/abstractairanica.29142

ISSN : 1961-960X

Éditeur :

CNRS (UMR 7528 Mondes iraniens et indiens), Éditions de l'IFRI

\section{Édition imprimée}

Date de publication : 15 mai 2008

ISSN : 0240-8910

Référence électronique

Bernard Hourcade, « Osțūre-ye Tehrān. Tehrān, Daftar-e pažūheš-hā-ye farhangī, 1385, 250 p. (Majmū'eye Tehrānšahr, 1) [Le mythe de Téhéran] », Abstracta Iranica [En ligne], Volume 29 | 2008, document 231, mis en ligne le 15 septembre 2008, consulté le 26 septembre 2020. URL : http://

journals.openedition.org/abstractairanica/29142; DOI : https://doi.org/10.4000/abstractairanica. 29142

Ce document a été généré automatiquement le 26 septembre 2020.

Tous droits réservés 


\section{Osțūre-ye Tehrān. Tehrān, Daftar-e pažūheš-hā-ye farhangī, 1385, $250 \mathrm{p}$. (Majmū'e-ye Tehrānšahr, 1) [Le mythe de Téhéran]}

\section{Bernard Hourcade}

Ce premier livre dans la collection "Tehrānšahr " fait une remarquable analyse de l'identité de Téhéran, de son image négative de ville poussiéreuse, sans âme, capitale sans passé, sans caractère, répandue par la plupart des voyageurs étrangers et même certains écrivains iraniens. L'analyse faite à travers les sources littéraires portant sur la période Qâjâr, mais aussi les romans contemporains, cherche à expliquer ce mythe de Téhéran qui est aujourd'hui peut-être dépassé et plus complexe mais toujours vivant. Un ouvrage de grande qualité qui devrait être suivi d'une prochaine étude sur Téhéran à travers le théâtre et les films.

\section{INDEX}

Thèmes : 4.3. Histoire de l'Iran moderne (à partir de 1905)

\section{AUTEURS}

\section{BERNARD HOURCADE}

CNRS - Mondes iranien et indien - Paris 